\title{
Effects of Replacing Dietary Starch with Sucrose on Ruminal Fermentation and Nitrogen Metabolism in Continuous Culture
}

\author{
J. E. Vallimont, ${ }^{1}$ F. Bargo, ${ }^{1}$ T. W. Cassidy, ${ }^{1}$ N. D. Luchini, ${ }^{2}$ \\ G. A. Broderick, ${ }^{3}$ and G. A. Varga ${ }^{1}$ \\ ${ }^{1}$ Department of Dairy and Animal Science, The Pennsylvania State University, \\ University Park 16802 \\ ${ }^{2}$ Bioproducts, Inc., Fairlawn, $\mathrm{OH} 44333$ \\ ${ }^{3}$ U.S. Dairy Forage Research Center, Madison, WI 53706
}

\section{ABSTRACT}

A dual-effluent continuous-culture system was used to evaluate the effects of partially replacing cornstarch with sucrose in a total mixed ration on ruminal fermentation and $\mathrm{N}$ metabolism. The 4 treatments were 0 (control), 2.5, 5.0, and 7.5\% sucrose and, respectively, 7.5 (control), 5.0, 2.5, and $0 \%$ cornstarch in a total mixed ration containing $20 \%$ corn silage and $40 \%$ alfalfa silage. Fermenters were fed 4 times a day during four 9$\mathrm{d}$ periods with sampling beginning on $\mathrm{d} 6$. Replacing cornstarch with sucrose did not alter ruminal $\mathrm{pH}$ (5.97), total volatile fatty acids (VFA) $(104.4 \mathrm{mmol} / \mathrm{L})$, or the acetate to propionate ratio (2.16); however, branchedchain volatile fatty acids were higher for the control treatment compared with the $7.5 \%$ sucrose treatment. Five hours postfeeding, sucrose treatments significantly altered molar proportions of all volatile fatty acids, and acetate-to-propionate and glucogenic-to-lipogenic ratios. Digestibility of dry matter and $\mathrm{N}$ were not affected by treatment, but digestibility of total nonstructural carbohydrates was increased with sucrose treatments. A quadratic effect was noted for neutral detergent fiber (NDF) digestibility as sucrose replaced starch. A higher NDF digestibility (66.1 vs. 59.9\%) was observed for the $7.5 \%$ sucrose treatment compared with the other 2 sucrose treatments. Levels of ammonia $\mathrm{N}$ were within an acceptable range to support microbial protein synthesis and did not differ among treatments (mean $=9.23 \mathrm{mg} / \mathrm{dL})$. Sucrose inclusion in the total mixed ration did not affect bacterial $\mathrm{N}$ synthesis. Results indicate that (at the levels tested in this study) inclusion of sucrose in the diet when rumen-degradable protein is adequate does not affect ruminal fermentation.

(Key words: sucrose, continuous culture, ruminal fermentation, bacterial nitrogen)

Received April 23, 2004.

Accepted August 16, 2004.

Corresponding author: G. A. Varga; e-mail: gvarga@psu.edu.
Abbreviation key: $\mathbf{0 S}=7.5 \%$ corn starch $+0 \%$ sucrose treatment, $\mathbf{2 . 5 S}=5 \%$ corn starch $+2.5 \%$ sucrose treatment, $\mathbf{5 S}=2.5 \%$ corn starch $+5 \%$ sucrose treatment, $\mathbf{7 . 5 S}=0 \%$ starch $+7.5 \%$ sucrose treatment, $\mathbf{N S C}=$ nonstructural carbohydrates.

\section{INTRODUCTION}

Sugars, starches, and other carbohydrates such as galactans and pectin constitute the highly digestible NFC and are the primary dietary sources of energy for the high-producing dairy cow (Varga, 2003). The fermentation of different NFC sources varies in digestion characteristics and in the profiles of organic acids produced (Hall and Herejk, 2001). The dietary NFC portion of the ration must be formulated to balance dietary fiber, which is necessary to maintain milk fat production and rumen health. Increased rate and extent of carbohydrate availability to rumen microorganisms can positively impact microbial protein synthesis. It has been hypothesized (Nocek and Russell, 1988) that the rate of substrate fermentation is roughly proportional to the rate of microbial growth, with more rapidly fermented substrates yielding more microbial mass. However, there is a risk of ruminal acidosis, which can occur when there is too much rapidly fermentable carbohydrate in the diet.

Sugars are rapidly fermented in the rumen, and both sugar and starch can be fermented to lactic acid in the rumen (Hungate, 1966). Strobel and Russell (1986) compared fermentation end products from sucrose and starch at 2 different $\mathrm{pH}$ levels (5.5 vs. 6.7) and found that sucrose and starch had similar microbial protein yields at the higher $\mathrm{pH}$; however, the microbial protein yield from sucrose was reduced by $34 \%$ at pH 5.5. Hall and Herejk (2001) compared the fermentation of starch, sugar, or pectin when fermented with indigestible NDF from bermudagrass and reported that starch fermentation resulted in the greatest yield of microbial protein.

Feeding diets higher in fermentable carbohydrates to prepartum dairy cows may increase milk yield and 
Table 1. Ingredient and chemical composition of diets fed to the fermenters.

\begin{tabular}{|c|c|c|c|c|}
\hline \multirow[b]{2}{*}{ Item } & \multicolumn{4}{|c|}{ Treatment $^{1}$} \\
\hline & OS & $2.5 \mathrm{~S}$ & $5.0 \mathrm{~S}$ & $7.5 \mathrm{~S}$ \\
\hline Alfalfa silage & 40.0 & 40.0 & 40.0 & 40.0 \\
\hline Corn silage & 20.0 & 20.0 & 20.0 & 20.0 \\
\hline Rolled high-moisture shelled corn & 20.5 & 20.5 & 20.5 & 20.5 \\
\hline Soybean meal (48\% CP) & 9.0 & 9.0 & 9.0 & 9.0 \\
\hline Bypass fat & 2.0 & 2.0 & 2.0 & 2.0 \\
\hline Sodium bicarbonate & 0.4 & 0.4 & 0.4 & 0.4 \\
\hline Dicalcium phosphate & 0.2 & 0.2 & 0.2 & 0.2 \\
\hline Salt & 0.3 & 0.3 & 0.3 & 0.3 \\
\hline Vitamins and minerals $^{2}$ & 0.1 & 0.1 & 0.1 & 0.1 \\
\hline Sucrose & 0.0 & 2.5 & 5.0 & 7.5 \\
\hline Corn starch & 7.5 & 5.0 & 2.5 & 0.0 \\
\hline \multicolumn{5}{|l|}{ Chemical composition } \\
\hline $\mathrm{CP}$ & 16.6 & 16.7 & 16.8 & 16.9 \\
\hline NDF & 30.0 & 29.2 & 29.6 & 29.6 \\
\hline $\mathrm{ADF}$ & 20.7 & 20.0 & 20.8 & 20.5 \\
\hline NFC & 42.7 & 43.7 & 42.6 & 42.8 \\
\hline NDIN $^{3}$ & 3.0 & 3.3 & 3.3 & 2.8 \\
\hline $\mathrm{ADIN}^{4}$ & 1.7 & 2.0 & 1.8 & 1.7 \\
\hline Fat & 4.0 & 4.0 & 4.0 & 4.0 \\
\hline $\mathrm{NSC}^{5}$ & 30.9 & 32.5 & 31.6 & 31.5 \\
\hline Starch $^{6}$ & 28.2 & 27.4 & 24.5 & 21.5 \\
\hline Sucrose $^{6}$ & 2.7 & 5.1 & 7.1 & 10.0 \\
\hline
\end{tabular}

${ }^{1} 0 \mathrm{~S}=0 \%$ Sucrose, $2.5 \mathrm{~S}=2.5 \%$ sucrose, $5.0 \mathrm{~S}=5.0 \%$ sucrose, and $7.5 \mathrm{~S}=7.5 \%$ sucrose

${ }^{2}$ Provided $56 \mathrm{mg}$ of $\mathrm{Zn}, 46 \mathrm{mg}$ of $\mathrm{Mn}, 22 \mathrm{mg}$ of Fe, $12 \mathrm{mg}$ of $\mathrm{Cu}$, $0.9 \mathrm{mg}$ of I, $0.4 \mathrm{mg}$ of Co, $0.3 \mathrm{mg}$ of Se, $6440 \mathrm{IU}$ of vitamin A, 2000 IU of vitamin $\mathrm{D}$, and 16 IU of vitamin $\mathrm{E} / \mathrm{kg}$ of $\mathrm{DM}$.

${ }^{3} \mathrm{NDIN}=$ Neutral detergent insoluble $\mathrm{N}$.

${ }^{4} \mathrm{ADIN}=$ Acid detergent insoluble $\mathrm{N}$.

${ }^{5} \mathrm{NSC}=$ Nonstructural carbohydrates (Smith, 1981).

${ }^{6}$ Miller-Webster and Hoover, (1998).

reduce metabolic diseases by increasing energy intake (Ordway et al., 2002). Providing rapidly fermentable carbohydrate sources may promote ruminal papillae development and increase VFA absorption, therefore enhancing the transition from nonlactating to lactating cow diets (Ordway et al., 2002). Sucrose stimulated DMI (Broderick et al., 2000) and enhanced rumen microbial protein synthesis (Khalili and Huhtanen, 1991). Increasing the supply of ruminally fermentable carbohydrates reduced ruminal ammonia concentration and increased milk protein yield (Sannes et al., 2002). The objectives of this study were to determine the effects on ruminal nutrient digestibility and bacterial $\mathrm{N}$ synthesis when dietary cornstarch was partially replaced by sucrose using dual-flow continuous-culture fermenters.

\section{MATERIALS AND METHODS}

\section{Experimental Design and Treatments}

Four diets were evaluated in continuous-culture fermenters using a completely randomized design. The 4 diets were: (1) $7.5 \%$ cornstarch $+0 \%$ sucrose (0S), (2)
Table 2. Chemical composition of the forages fed in the experimental diets.

\begin{tabular}{lcl}
\hline & Corn silage & Alfalfa silage \\
\hline DM, \% & 33.3 & 42.0 \\
CP, \% of DM & 8.5 & 21.9 \\
ADF, \% of DM & 24.9 & 33.8 \\
NDF, \% of DM & 43.8 & 42.5 \\
Ash, \% of DM & 4.6 & 9.8 \\
\hline
\end{tabular}

$5.0 \%$ cornstarch $+2.5 \%$ sucrose $(\mathbf{2 . 5 S}),(3) 2.5 \%$ cornstarch $+5.0 \%$ sucrose $(\mathbf{5 S})$, and (4) $0 \%$ starch $+7.5 \%$ sucrose (7.5S). The ingredient and chemical composition of the diets are described in Table 1. Samples of the different TMR fed were dried at $55^{\circ} \mathrm{C}$. Chemical composition of the forages used in the study is presented in Table 2.

\section{Continuous-Culture Operation}

A dual-effluent continuous-culture system with 4 units with volume ranging from 1015 to $1040 \mathrm{~mL}$ was used in the study. This system is similar to that described by Hoover et al. (1989). Five liters of ruminal fluid were collected with a hand pump from a ruminally cannulated Holstein cow $3 \mathrm{~h}$ after feeding. Approximately $300 \mathrm{~g}$ of whole ruminal digesta was collected from that cow at the same time. Liquid and digesta samples were placed in separate insulated containers. Within 15 min after collection, each fermenter was inoculated with approximately $1000 \mathrm{~mL}$ of rumen fluid and $30 \mathrm{~g}$ of whole digesta. Each fermenter was fed the assigned diet at a rate of $75 \mathrm{~g}$ of $\mathrm{DM} / \mathrm{d}$ in 4 equal feedings at $0700,1200,1700$, and $2200 \mathrm{~h}$. Diets were ground through a $4-\mathrm{mm}$ mesh screen. Liquid dilution rate was $0.11 / \mathrm{h}$ and solids retention time was $24 \mathrm{~h}$ (Crawford et al., 1980).

The fermenters were operated for 4 periods and each period had a length of $9 \mathrm{~d}$, consisting of a 6 -d adjustment period followed by a 3 -d sampling period. Fermenter $\mathrm{pH}$ was recorded 4 times daily at the time of feeding. On d 7 to 9 , effluent samples were collected daily, composited, and freeze-dried for analysis of DM, ash (AOAC, 1990), CP (AOAC, 1990), NDF (Van Soest et al., 1991), nonstructural carbohydrates (NSC; Smith, 1981), and purines (Zinn and Owens, 1986). Samples were also collected for analysis of ammonia and VFA (Yang and Varga, 1989). On d 9, samples were taken from fermenters at $0,1,2,3,4$, and $5 \mathrm{~h}$ after feeding for analysis of ammonia and VFA (Yang and Varga, 1989). In addition, at $1200 \mathrm{~h}$ on $\mathrm{d} 9$, entire fermenter contents were used to harvest microbial protein (Vazquez-Añon et al., 2001). Bacteria samples were freezedried and analyzed for DM, N, and purines (Bargo et al., 2003). 
Table 3. Ruminal $\mathrm{pH}$ and volatile fatty acids (VFA) average of d 7 to 9 in continuous culture fermenters fed diets with increasing levels of sucrose.

\begin{tabular}{|c|c|c|c|c|c|c|c|}
\hline \multirow[b]{2}{*}{ Item } & \multicolumn{4}{|c|}{ Treatments $^{1}$} & \multirow[b]{2}{*}{ SEM } & \multicolumn{2}{|c|}{$P^{2}$} \\
\hline & $0 \mathrm{~S}$ & $2.5 \mathrm{~S}$ & $5.0 \mathrm{~S}$ & $7.5 \mathrm{~S}$ & & $\mathrm{~L}$ & $\mathrm{Q}$ \\
\hline $\mathrm{pH}$ & 6.05 & 5.93 & 5.91 & 5.97 & 0.08 & 0.22 & 0.28 \\
\hline $\begin{array}{l}\text { Total VFA, } \mathrm{mmol} / \mathrm{L} \\
\text { VFA, mol/100 } \mathrm{mol}\end{array}$ & 105.8 & 105.1 & 103.0 & 103.6 & 2.18 & 0.59 & 0.77 \\
\hline Acetate (A) & 56.5 & 56.8 & 55.4 & 54.7 & 0.75 & 0.94 & 0.51 \\
\hline Propionate $(\mathrm{P})$ & 28.1 & 26.9 & 26.0 & 26.4 & 1.26 & 0.35 & 0.50 \\
\hline Butyrate & 15.1 & 15.7 & 16.3 & 17.2 & 0.88 & 0.75 & 0.84 \\
\hline Isobutyrate & 0.65 & 0.56 & 0.54 & 0.52 & 0.03 & 0.08 & 0.26 \\
\hline Valerate & 3.66 & 3.57 & 3.15 & 3.35 & 0.22 & 0.32 & 0.51 \\
\hline Isovalerate & 1.75 & 1.69 & 1.56 & 1.42 & 0.11 & 0.77 & 0.68 \\
\hline $\mathrm{A}: \mathrm{P}$ ratio $^{3}$ & 2.09 & 2.22 & 2.25 & 2.09 & 0.10 & 0.15 & 0.14 \\
\hline Gluc:Lip ratio ${ }^{3}$ & 0.39 & 0.37 & 0.36 & 0.37 & 0.02 & 0.59 & 0.77 \\
\hline
\end{tabular}

${ }^{1} 0 \mathrm{~S}=0 \%$ Sucrose, $2.5 \mathrm{~S}=2.5 \%$ sucrose, $5 \mathrm{~S}=5 \%$ sucrose, and $7.5 \mathrm{~S}=7.5 \%$ sucrose.

${ }^{2}$ Probability of a significant effect of treatment (T), or linear (L) and quadratic (Q) effects of treatment level.

${ }^{3} \mathrm{~A}: \mathrm{P}$ ratio $=$ Acetate to propionate ratio, Gluc:Lip Ratio = gluconeogenic to lipogenic ratio.

\section{Statistical Analyses}

The average of the $8 \mathrm{pH}$ measurements taken from d 7 to 8 of each period was used to represent the average $\mathrm{pH}$ for each treatment at each period. Mean ammonia and VFA treatment values were calculated from the average of the samples collected at $1200 \mathrm{~h}$ on d 6 to 8 of each period. These data were analyzed separately from the ammonia and VFA concentrations measured during the first $5 \mathrm{~h}$ postfeeding on $\mathrm{d} 9$ of each period. The average of the ammonia and VFA measurements in samples taken each period at each hour over all 4 periods represented the ammonia or VFA value for each hour.

The effect of supplemental sucrose on nutrient digestion and bacterial $\mathrm{N}$ synthesis was analyzed using the MIXED procedure of SAS (Version 8.2, 1995). The effects of replacing cornstarch with sucrose in a TMR on ruminal fermentation, nutrient digestibility, and $\mathrm{N}$ metabolism were analyzed as a completely randomized design. Orthogonal polynomials were used to test linear and quadratic responses for increasing levels of sucrose.

Significance was declared at $P<0.05$ and trends at $P<0.10$.

Sources of variation in the model included treatment and period. The interaction of treatment by period was not included in the analyses, because it was not significant. Differences among treatments were evaluated with least square means. For the hourly measurements of ammonia and VFA, the model included treatment and hour; the interaction of treatment $\times$ hour was not significant $(P>0.05)$.

\section{RESULTS AND DISCUSSION}

\section{Ruminal pH and VFA}

Ruminal samples for VFA measurements are presented separately for the treatment averages calculated with the samples collected at $1200 \mathrm{~h}$ from d 7 to 9 (Table 3 ) and for the first $5 \mathrm{~h}$ postfeeding on d 9 (Table 4; Figure 1). Replacing dietary starch with sucrose did not affect $(P>0.05)$ ruminal $\mathrm{pH}$ and averaged 5.97 (Table 3). These results support those obtained in the companion study (Broderick et al., 2000), where ruminal $\mathrm{pH}$ of dairy cows was similar among treatments and averaged 6.19. Ruminal $\mathrm{pH}$ was not affected by including $3.2 \%$ of sucrose in the diet and averaged 6.02 (Sannes et al., 2002). Others (Khalili and Huhtanen, 1991; Lee et al., 2003) reported significant effect of sucrose inclusion in the diet on ruminal $\mathrm{pH}$. Lee et al. (2003) found a linear reduction in ruminal $\mathrm{pH}$ from 6.4 to 6.0 as sugar infusion levels increased. Differences between that study and our study could be attributed to the fact that in the study of Lee et al. (2003), sucrose infusion increased linearly the total content of NSC in the diet, whereas in our study, replacing sucrose for starch did not affect the NSC content in the diet (Table 1).

Average total VFA concentration was not affected ( $P$ $>0.05$ ) by replacing starch for sucrose and averaged $104.4 \mathrm{mmol} / \mathrm{L}$ (Table 3). The companion animal study (Broderick et al., 2000) also reported no differences in total VFA concentration (107.2 $\mathrm{mmol} / \mathrm{L})$. This agrees with a previous study (Sannes et al., 2002) reporting no effect of including $3.2 \%$ of sucrose in the diet on total VFA concentration (127.1 mmol/L). Lee et al. (2003) 
Table 4. Volatile fatty acids during the first feeding cycle in continuous culture fermenters fed diets with increasing levels of sucrose.

\begin{tabular}{|c|c|c|c|c|c|c|c|}
\hline \multirow[b]{2}{*}{ Item } & \multicolumn{4}{|c|}{ Treatments $^{1}$} & \multirow[b]{2}{*}{ SEM } & \multicolumn{2}{|c|}{$P^{2}$} \\
\hline & $0 \mathrm{~S}$ & $2.5 \mathrm{~S}$ & $5.0 \mathrm{~S}$ & $7.5 \mathrm{~S}$ & & $\mathrm{~L}$ & $\mathrm{Q}$ \\
\hline Total VFA, mmol/L & 92.1 & 93.2 & 85.8 & 83.6 & 1.98 & 0.88 & 0.44 \\
\hline Ammonia $\mathrm{N}, \mathrm{mg} / \mathrm{dL}$ & 11.5 & 9.7 & 10.0 & 12.6 & 1.68 & 0.83 & 0.98 \\
\hline \multicolumn{8}{|l|}{ VFA, mol/100 mol } \\
\hline Acetate & 49.2 & 49.2 & 45.3 & 44.7 & 1.23 & 0.76 & 0.82 \\
\hline Propionate & 24.9 & 24.5 & 21.8 & 19.6 & 0.54 & 0.76 & 0.11 \\
\hline Butyrate & 12.2 & 13.8 & 13.7 & 14.2 & 0.25 & 0.02 & 0.09 \\
\hline Isobutyrate & 0.56 & 0.53 & 0.53 & 0.56 & 0.001 & 0.01 & 0.01 \\
\hline Valerate & 3.49 & 3.44 & 2.86 & 2.90 & 0.019 & 0.06 & 0.50 \\
\hline Isovalerate & 1.77 & 1.89 & 1.68 & 1.73 & 0.010 & 0.53 & 0.32 \\
\hline $\mathrm{A}: \mathrm{P}$ ratio $^{3}$ & 1.98 & 2.01 & 2.08 & 2.29 & 0.025 & 0.06 & 0.01 \\
\hline Gluc:Lip Ratio ${ }^{3}$ & 0.40 & 0.39 & 0.37 & 0.33 & 0.004 & 0.69 & 0.01 \\
\hline
\end{tabular}

\footnotetext{
${ }^{1} 0 \mathrm{~S}=0 \%$ Sucrose, $2.5 \mathrm{~S}=2.5 \%$ sucrose, $5 \mathrm{~S}=5 \%$ sucrose, and $7.5 \mathrm{~S}=7.5 \%$ sucrose.

${ }^{2}$ Probability of a significant effect of treatment (T), or linear (L) and quadratic (Q) effects of treatment level.

${ }^{3} \mathrm{~A}: \mathrm{P}$ ratio $=$ Acetate to propionate ratio, Gluc:Lip Ratio $=$ gluconeogenic to lipogenic ratio.
}

reported a linear increase in total VFA concentration from 133.3 to $143.1 \mathrm{mmol} / \mathrm{L}$ as the amount of sucrose was infused into the rumen increased linearly. No differences $(P>0.05)$ in molar proportion of most of the individual VFA was found among diets, except for the molar proportion of isobutyrate that was linearly reduced $(P=0.08)$ with the inclusion of sucrose (Table 3). Similarly, Broderick et al. (2000) found that the molar proportion of isobutyrate and isovalerate were decreased for the 7.5S treatment compared with the control treatment. The acetate to propionate ratio was linearly $(P=0.06)$ and quadratically $(P=0.01)$ reduced as starch was replaced by sucrose (Table 3 ). Khalili and Huhtanen (1991) reported that sucrose supplementation decreased molar proportions of acetate and isovalerate, and increased molar proportions of butyrate and valerate. Lee et al. (2003) reported significant decreases in quantities of propionate and butyrate, and increased acetate when fresh perennial ryegrass was fermented in vitro with increasing amounts of sucrose. In the current study, adequate RDP was available to the rumen microbes, whereas available $\mathrm{N}$ may have been limiting in the study of Lee et al. (2003). Fermentation of sucrose by rumen microbes resulted in similar concentrations of acetate and propionate as compared with starch, but more butyrate and lactate at $\mathrm{pH} 6.7$ (Strobel and Russell, 1986). At a more acidic $\mathrm{pH}$ (5.5), fermentation of sucrose produced more lactate, less acetate and butyrate, and the same amount of propionate compared with starch fermentation (Strobel and Russell, 1986). Inclusion of sucrose increased the concentration of lactic acid in the rumen, decreased the molar proportion of acetic acid, and increased the molar proportions of propionic and butyric acids (Sutton, 1997). Sannes et al. (2002) also reported a decrease in total branched-chain VFA when a portion of the corn was replaced by sucrose in a TMR fed to lactating cows. Branched-chain VFA are produced in the rumen from deamination and decarboxylation of branched-chain AA (Allison, 1970). Broderick et al. (2000) observed that total ruminal AA were reduced with sucrose diets compared with starch diets; therefore, this may explain the reduced branched VFA with sucrose feeding.

There was a treatment effect $(P<0.01)$ for total VFA during the $5 \mathrm{~h}$ postfeeding (Table 4 ). Total VFA concentration during the $5 \mathrm{~h}$ postfeeding was higher $(P<0.01)$ for the control treatment compared with the $5 \mathrm{~S}$ and $7.5 \mathrm{~S}$ treatments $(92.1 \mathrm{vs} .85 .8$ and $83.6 \mathrm{mmol} / \mathrm{L}$, respectively), but did not differ $(P>0.05)$ with the $2.5 \mathrm{~S}$ treatment. Acetate molar proportion in the control diet also did not differ $(P>0.05)$ compared with the $2.5 \mathrm{~S}$ treatment, but was higher $(P<0.01)$ compared with the $5 \mathrm{~S}$ and $7.5 \mathrm{~S}$ treatments $(49.2$ vs. 45.3 and $44.7 \mathrm{~mol} / 100$ mol, respectively; Table 4 and Figure 1a). The molar proportion of propionate did not differ $(P>0.05)$ between the $0 \mathrm{~S}$ and $2.5 \mathrm{~S}$ treatments, but was higher $(P$ $<0.01$ ) in the control treatment compared with both the $5 \mathrm{~S}$ and $7.5 \mathrm{~S}$ treatments (24.9 vs. 21.8 and $19.6 \mathrm{~mol} /$ 100 mol, respectively; Figure 1b). Replacing starch with sucrose gave linear $(P=0.02)$ and quadratic $(P=0.09)$ increases in the molar proportion of butyrate (Figure 1c). Isobutyrate molar proportion was linearly and quadratically affected $(P=0.01)$ by increasing the inclusion of sucrose in the diet. Molar proportion of valerate was linearly reduced $(P=0.06)$ from 3.49 to $2.90 \mathrm{~mol} / 100$ mol with increased dietary sucrose. The acetate to propionate and glucogenic to lipogenic ratios were quadratically affected $(P=0.01)$ by replacing starch for sucrose in the diet. These differences in postfeeding VFA levels 
A

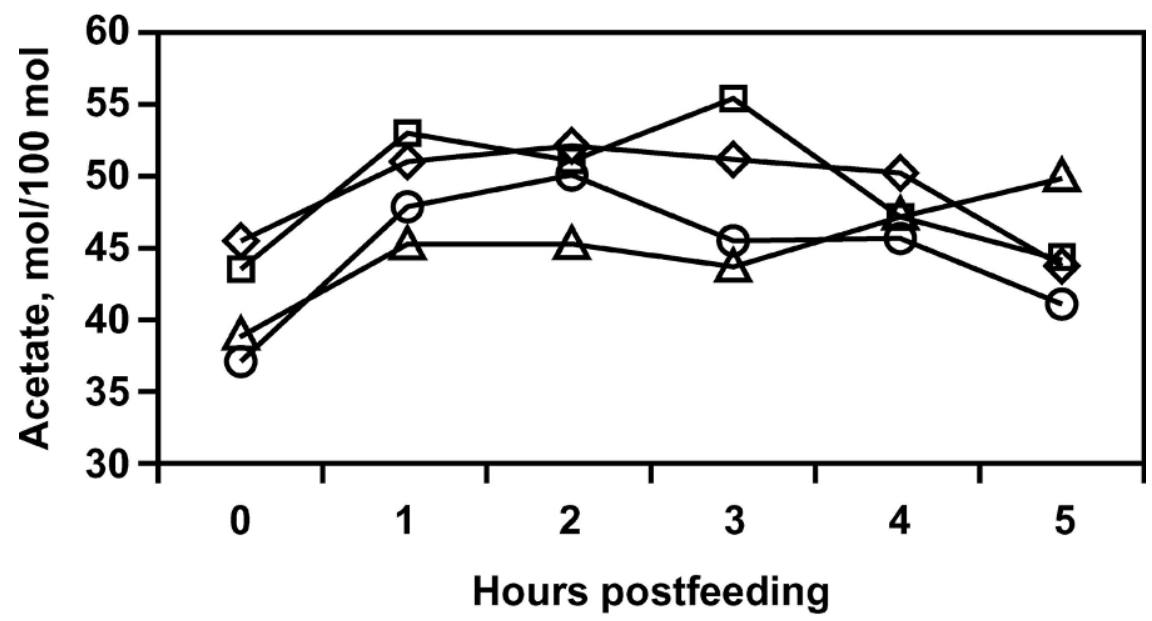

B

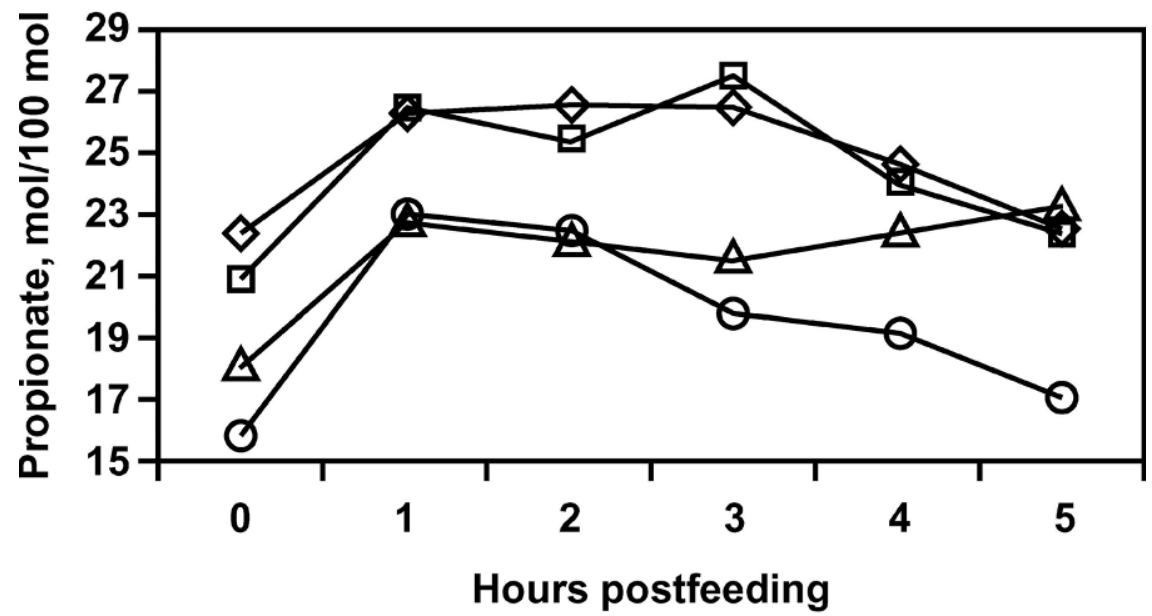

C

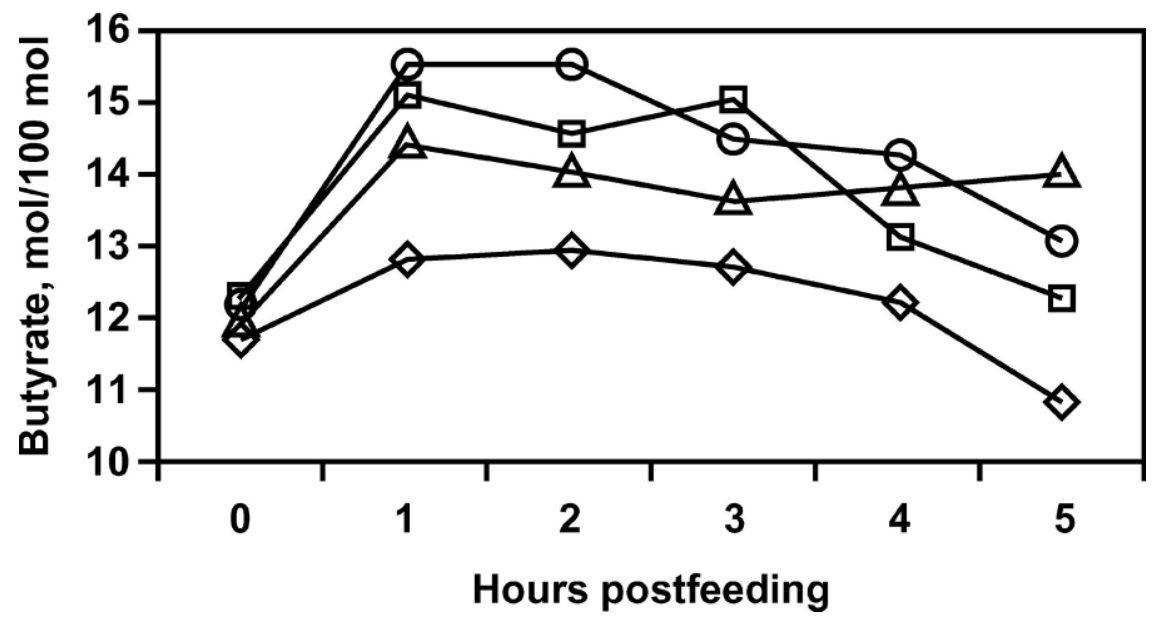

Figure 1. Acetate (A), propionate (B), and butyrate (C) proportions (mol/100 mol) after feeding $(0 \mathrm{~h})$ in continuous-culture fermenters fed diets with $0(\diamond), 2.5(\square), 5.0(\triangle)$, or $7.5 \%(\bigcirc)$ sucrose. Effects of treatment and hour were significant $(P<0.05)$ for acetate, propionate, and butyrate. 
Table 5. Apparent digestibility of nutrients in continuous culture fermenters fed diets with increasing levels of sucrose.

\begin{tabular}{lllllllll}
\hline & \multicolumn{4}{c}{ Treatments $^{1}$} & & \multicolumn{2}{c}{$P^{2}$} \\
\cline { 2 - 4 } \cline { 6 - 8 } Item & $0 \mathrm{~S}$ & $2.5 \mathrm{~S}$ & $5.0 \mathrm{~S}$ & $7.5 \mathrm{~S}$ & SEM & $\mathrm{L}$ & $\mathrm{Q}$ \\
\hline $\mathrm{DM}$ & 47.5 & 46.0 & 46.6 & 47.0 & 1.21 & 0.42 & 0.43 \\
$\mathrm{NDF}$ & 61.3 & 58.5 & 59.4 & 66.1 & 2.24 & 0.13 & 0.05 \\
$\mathrm{~N}$ & 49.4 & 45.8 & 47.6 & 48.4 & 1.57 & 0.20 & 0.20 \\
$\mathrm{NSC}^{3}$ & 82.9 & 83.7 & 82.6 & 85.3 & 0.63 & 0.50 & 0.22 \\
\hline
\end{tabular}

${ }^{1} 0 \mathrm{~S}=0 \%$ Sucrose, $2.5 \mathrm{~S}=2.5 \%$ sucrose, $5 \mathrm{~S}=5 \%$ sucrose, and $7.5 \mathrm{~S}=$ $7.5 \%$ sucrose.

${ }^{2}$ Probability of a significant effect of treatment (T), or linear (L) and quadratic $(\mathrm{Q})$ effects of treatment level.

${ }^{3} \mathrm{NSC}=$ Nonstructural carbohydrates.

confirm that the ruminal fermentation was altered as a result of sucrose feeding.

Ordway et al. (2002) reported a numerical trend toward increased milk fat percentage (3.76 vs. $3.54 \%)$ when sucrose substituted for $2.7 \%$ the ground corn in prepartum diet. Broderick et al. (2000) reported an increase in milk fat percentage (4.16 vs. $3.81 \%)$ and yield $(1.62 \mathrm{vs} .1 .47 \mathrm{~kg} / \mathrm{d})$ for the $7.5 \mathrm{~S}$ treatment in the companion lactation study. Butyrate is a substrate in de novo fatty acid synthesis (Van Soest, 1994), and the increased butyrate observed in the $7.5 \mathrm{~S}$ treatment during the first $5 \mathrm{~h}$ postfeeding (Table 4 ) may explain the increased milk fat production in cows supplemented with sucrose. The decrease in the glucogenic to lipogenic ratio and the increase in the acetate to propionate ratio observed during the first $5 \mathrm{~h}$ postfeeding in the current study (Table 4) may help explain the increased milk fat reported by Broderick et al. (2000).

\section{Digestibility of Nutrients}

Apparent digestibility of nutrients is shown in Table 5. Apparent digestibility of DM was not affected $(P>$ 0.05 ) as sucrose replaced starch in the diet and averaged $46.8 \%$. Digestibility of DM in all treatments was similar to those previously reported for typical TMR for high-producing dairy cows in continuous culture (approximately 50\%; Vazquez-Añon et al., 2001). Apparent digestibility of NDF was quadratically affected $(P=$ $0.05)$ as sucrose increased in the diet. Inclusion of $7.5 \%$ of sucrose in the diet resulted in higher $(P<0.05) \mathrm{NDF}$ digestibility compared with the $2.5 \mathrm{~S}$ and $5 \mathrm{~S}$ treatment ( 66.1 vs. 58.5 and $59.4 \%$, respectively) whereas the control diet was intermediate $(61.3 \%$; Table 5$)$. The increase in NDF digestibility for the highest level of sucrose compared with the other levels of sucrose may reflect a shift in microbial populations or growth among the ruminal microbes present. These results suggest that NDF digestibility partially accounts for the linear increase in DMI reported for lactating cows in the com- panion study (Broderick et al., 2000). Nombekela and Murphy (1995) found that overall DMI was not enhanced by $1.5 \%$ sucrose supplementation compared with a control diet; however, sucrose transiently increased DMI during the first 2 wk postpartum. It is also possible that sucrose improved ration palatability or increased rate of passage from the rumen (Khalili and Huhtanen, 1991), enhancing the increment in DMI observed by Broderick et al. (2000). Several studies have reported reduced rate and extent of NDF digestibility when sucrose is added to the ration (Huhtanen and Khalili, 1991; Khalili and Huhtanen, 1991; Heldt et al., 1999). This effect may be due to the NFC-fermenting bacteria competing with the fiber-digesting bacteria for available $\mathrm{N}$, and that the inclusion of adequate quantities of RDP in the diet may prevent sucrose from decreasing NDF digestibility (Jones et al., 1998; Lee et al., 2003). Other studies (Huhtanen and Khalili, 1991), however, reported higher NDF digestibility with diets including $1 \mathrm{~kg} / \mathrm{d}$ of sucrose fed twice daily. Based on the evaluation of these diets using the Cornell Net Carbohydrate Protein System (V4.026), the RDP in the experimental diets fed in the current study was not limiting to NDF- or NFC-fermenting bacteria.

Apparent digestibility of $\mathrm{N}$ was not affected by the inclusion of sucrose in the diet and averaged $47.8 \%$ (Table 5). In a review of molasses use in beef cattle nutrition, Pate (1983) discussed several studies that reported decreased DM and $\mathrm{N}$ digestibility when molasses was included in the ration depending on the level of molasses in the ration. Pate (1983) concluded that negative effects on nutrient digestibility were generally related to inadequate $\mathrm{N}$ to meet the needs of the rumen microbes or the animal, or both. Apparent digestibility of NSC was higher $(P<0.01)$ for the $7.5 \mathrm{~S}$ treatment compared with the control treatment ( 85.3 vs. $82.9 \%$ ), which did not differ $(P>0$. 05) from the $2.5 \mathrm{~S}$ and $5 \mathrm{~S}$ treatments (Table 5). The higher NSC digestibility may reflect a change in the bacterial populations with additional sucrose (Hungate, 1966).

\section{Nitrogen Metabolism}

Nitrogen metabolism data when sucrose replaced starch are presented in Table 6 . Ammonia $\mathrm{N}$ concentration was not affected $(P>0.05)$ by treatments and averaged $9.22 \mathrm{mg} / \mathrm{dL}$. In the companion study, Broderick et al. (2000) reported a trend for decreased ammonia N ( 6.9 to $5.8 \mathrm{mg} / \mathrm{dL}$ ) with increasing sucrose in the diet. Other studies in which sucrose was included in the ration showed a reduction in ruminal ammonia $\mathrm{N}$ concentration (McCormick et al., 2001; Sannes et al., 2002; Lee et al., 2003). Sannes et al. (2002) reported that ruminal ammonia $\mathrm{N}$ concentration tended to be reduced 
Table 6. Nitrogen metabolism in continuous culture fermenters fed diets with increasing levels of sucrose.

\begin{tabular}{|c|c|c|c|c|c|c|c|}
\hline \multirow[b]{2}{*}{ Item } & \multicolumn{4}{|c|}{ Treatments $^{1}$} & \multirow[b]{2}{*}{ SEM } & \multicolumn{2}{|c|}{$P^{2}$} \\
\hline & oS & $2.5 \mathrm{~S}$ & $5.0 \mathrm{~S}$ & $7.5 \mathrm{~S}$ & & $\mathrm{~L}$ & $\mathrm{Q}$ \\
\hline $\begin{array}{l}\text { Ammonia } \mathrm{N}, \mathrm{mg} / \mathrm{dL} \\
\mathrm{N} \text { flow, } \mathrm{g} / \mathrm{d}\end{array}$ & 9.66 & 8.70 & 9.18 & 9.36 & 0.54 & 0.31 & 0.31 \\
\hline Ammonia & 0.25 & 0.23 & 0.24 & 0.23 & 0.01 & 0.65 & 0.79 \\
\hline Dietary & 0.70 & 0.71 & 0.70 & 0.65 & 0.07 & 0.74 & 0.63 \\
\hline Bacterial & 1.03 & 1.12 & 1.07 & 1.10 & 0.09 & 0.61 & 0.69 \\
\hline Bacterial N & & & & & & & \\
\hline $\mathrm{N}$ flow, $\%$ & 52.0 & 54.4 & 53.0 & 55.8 & 3.76 & 0.86 & 0.98 \\
\hline DM, \% & 7.80 & 7.87 & 7.98 & 7.67 & 0.31 & 0.57 & 0.54 \\
\hline DM digested, g/kg & 29.0 & 32.4 & 30.4 & 31.2 & 2.83 & 0.51 & 0.58 \\
\hline
\end{tabular}

${ }^{1} 0 \mathrm{~S}=0 \%$ Sucrose, $2.5 \mathrm{~S}=2.5 \%$ sucrose, $5 \mathrm{~S}=5 \%$ sucrose, and $7.5 \mathrm{~S}=7.5 \%$ sucrose.

${ }^{2}$ Probability of a significant effect of treatment (T), or linear (L) and quadratic (Q) effects of treatment level.

from 4.92 to $3.89 \mathrm{~m} M$ with $3.2 \%$ sucrose inclusion in the diet of dairy cows. Chamberlain et al. (1985) reported a reduction in ruminal ammonia concentration due to sucrose supplementation of a grass silage diet and found that sucrose was more effective than starch in reducing ruminal ammonia concentration N. Substituting cornstarch with $5 \%$ sucrose reduced ruminal ammonia $\mathrm{N}$ concentration from 9.53 to $8.79 \mathrm{mg} / \mathrm{dL}$ in dairy cows fed a ryegrass-based diet (McCormick et al., 2001). Results from in vivo and in vitro experiments can differ because of the contribution of rumen recycled N. Obara et al. (1991) demonstrated that various factors enhance the permeability of the rumen wall to urea during increased carbohydrate fermentation. Increased butyrate production has been shown to stimulate ruminal papillae development (Van Soest, 1994) as well as cell proliferation (Obara et al., 1991). Increased cell proliferation has been shown to increase permeability of the rumen wall and allow greater recycling of urea into the rumen (Obara et al., 1991). This additional urea would result in more available ammonia $\mathrm{N}$ for the microbial populations in vivo.

Fluctuations in ammonia $\mathrm{N}$ concentration during the $5 \mathrm{~h}$ after feeding followed a similar pattern for all treatments, and treatment and hour were both highly significant $(P<0.01$; Figure 2$)$. Ammonia $\mathrm{N}$ concentrations increased during the first hour after feeding, especially in the 7.5S treatment (Figure 2); however, this did not translate into greater bacterial $\mathrm{N}$ synthesis. Hall and Herejk (2001) suggested that sucrose utilizers converted some portion of the sucrose to a storage polysaccharide; therefore, when the sucrose concentration declined, they used their stores for maintenance and maintained the microbial population. It is possible that the bacterial species within the fermenter environment shifted as a result of the lower amount of starch and the higher quantity of sucrose in the total ration, leading to higher ammonia $\mathrm{N}$ concentrations without an increase in bacterial $\mathrm{N}$. In addition, there may be interactions with other microbes that result in competition for ammonia $\mathrm{N}$ between NDF and NFC fermenting bacteria. High-starch diets induce a more prolonged period of bacterial polysaccharide accumulation than diets containing soluble sugars (Hall and Herejk, 2001).

Flows of the different $\mathrm{N}$ fractions were not affected $(P>0.05)$ when starch replaced sucrose (Table 6). Flow of ammonia $\mathrm{N}$, dietary $\mathrm{N}$, and bacterial $\mathrm{N}$ averaged $0.24,0.69$, and $1.08 \mathrm{~g} / \mathrm{d}$. When expressed as percentages of N flows or DM flows, bacterial $\mathrm{N}$ did not differ $(P>$ 0.05 ) among treatments, and averaged 53.8 and $7.8 \%$, respectively (Table 6). Efficiency of bacterial $\mathrm{N}$ synthesis was not affected $(P>0.05)$ by replacing starch with sucrose and averaged $30.8 \mathrm{~g} \mathrm{~N} / \mathrm{kg}$ DM digested (Table 6). Lee et al. (2003) reported a reduction in efficiency of bacterial $\mathrm{N}$ synthesis for fermenters infused with increasing amounts of sucrose and speculated that this reduction in efficiency was due to insufficient $\mathrm{N}$ available to the rumen microbes at the highest level of sucrose inclusion.

\section{CONCLUSIONS}

Replacing cornstarch with sucrose altered ruminal fermentation as evidenced by decreased proportions of isoacids at the highest level of sucrose inclusion, and by changes in ammonia $\mathrm{N}$ and VFA $5 \mathrm{~h}$ postfeeding. Sucrose inclusion in the diet resulted in increased NDF digestion, suggesting that RDP was not limiting in these diets. Total nonstructural carbohydrate digestibility was increased as sucrose was included in the ration. Bacterial $\mathrm{N}$ yield did not differ among treatments. Increasing sucrose in the diet especially at the highest level may have altered microbial populations such that they were less efficient at ammonia $\mathrm{N}$ capture. Given the increase in DMI reported in the companion in vivo trial (Broderick et al., 2000) and the lack of 




Figure 2. Ammonia concentrations after feeding $(0 \mathrm{~h})$ in continuous-culture fermenters fed diets with $0(\diamond), 2.5(\square), 5.0(\triangle)$, or $7.5 \%$ $(\bigcirc)$ sucrose. Effects of treatment and hour were significant $(P<0.05)$. Ammonia levels in fermenters treated with $0 \%$ sucrose differed from all other treatments $(P<0.05)$.

reduction in ruminal $\mathrm{pH}$ or $\mathrm{NDF}$ digestibility observed in this study, sucrose supplementation in lactating cow diets may be beneficial provided that RDP is not limiting for the microorganisms.

\section{REFERENCES}

Allison, M. J. 1970. Nitrogen metabolism of ruminal microorganisms. Page 456 in Physiology of Digestion and Metabolism in the Ruminant. A. T. Phillipson, ed. Oriel Press, Newcastle upon Tyne, UK. Association of Official Analytical Chemists. 1990. Official Methods of Analysis. 15th ed. AOAC, Arlington, VA.

Bargo, F., G. A. Varga, L. D. Muller, and E. S. Kolver. 2003. Pasture intake and substitution rate effects on nutrient digestion and nitrogen metabolism during continuous culture fermentation. J. Dairy Sci. 86:1330-1340.

Broderick, G. A., N. D. Luchini, W. J. Smith, S. Reynal, G. A. Varga, and V. A. Ishler. 2000. Effect of replacing dietary starch with sucrose on milk production in lactating dairy cows. J. Dairy Sci. 83(Suppl. 1):248.

Chamberlain, D. G., P. C. Thomas, W. Wilson, C. J. Newbold, and J. C. MacDonald. 1985. The effects of carbohydrate supplements on ruminal concentrations of ammonia in animals given diets of grass silage. J. Agric. Sci. (Camb.) 104:331-340.

Crawford, R. J., Jr., W. H. Hoover, and P. H. Knowlton. 1980. Effects of solids and liquid flows on fermentation in continuous cultures. I. Dry matter and fiber digestion, VFA production and protozoa numbers. J. Anim. Sci. 51:975-985.

Hall, M. B., and C. Herejk. 2001. Differences in yields of microbial crude protein from in vitro fermentation of carbohydrates. J. Dairy Sci. 84:2486-2493.
Heldt, J. S., R. C. Cochran, G. L. Stokka, C. G. Farmer, C. P. Mathis, E. C. Titgemeyer, and T. G. Nagaraja. 1999. Effects of different supplemental sugars and starch fed in combination with degradable intake protein on low-quality forage use by beef steers. J. Anim. Sci. 77:2793-2802.

Hoover, W. H., T. K. Miller, S. R. Stokes, and W. V. Thayne. 1989. Effects of fish meals on rumen bacterial fermentation in continuous culture. J. Dairy Sci. 72:2991-2998.

Huhtanen, P., and H. Khalili. 1991. Sucrose supplements in cattle given grass silage-based diet. 3. Rumen pool size and digestion kinetics. Anim. Feed Sci. Technol. 33:275-287.

Hungate, R. E. 1966. The Rumen and Its Microbes. Academic Press, Inc., New York, NY.

Jones, D. F., W. H. Hoover, and T. K. Miller-Webster. 1998. Effects of concentrations of peptides on microbial metabolism in continuous culture. J. Anim. Sci. 76:611-616.

Khalili, H., and P. Huhtanen. 1991. Sucrose supplements in cattle given grass silage-based diet. 2. Digestion of cell wall carbohydrates. Anim. Feed Sci. Technol. 33:263-273.

Lee, M. R. F., R. J. Merry, D. R. Davies, J. M. Moorby, M. O. Humphreys, M. K. Theodorou, J. C. MacRae, and N. D. Scollan. 2003. Effect of increasing availability of water-soluble carbohydrates on in vitro rumen fermentation. Anim. Feed Sci. Technol. 104:59-70.

McCormick, M. E., D. D. Redfearn, J. D. Ward, and D. C. Blouin. 2001. Effect of protein source and soluble carbohydrate addition on rumen fermentation and lactation performance of Holstein cows. J. Dairy Sci. 84:1686-1697.

Miller-Webster, T. K., and W. H. Hoover. 1998. Nutrient analysis of feedstuffs including carbohydrates. Anim. Sci. Report No.1. West Virginia Univ., Morgantown.

Nocek, J. E., and J. B. Russell. 1988. Protein and energy as an integrated system: Relationship of ruminal protein and carbohydrate 
availability to microbial synthesis and milk production. J. Dairy Sci. 71:2070-2107.

Nombekela, S. W., and M. R. Murphy. 1995. Sucrose supplementation and feed intake of dairy cows in early lactation. J. Dairy Sci. 78:880-885.

Obara, Y., D. W. Dellow, and J. V. Nolan. 1991. The influence of energy rich supplements on nitrogen kinetics in ruminants. Page 515 in Physiological Aspects of Digestion and Metabolism in Ruminants. Proc. 7th Int. Symp. Ruminant Phys., Academic Press, Inc., New York, NY.

Ordway, R. S., V. A. Ishler, and G. A. Varga. 2002. Effects of sucrose supplementation on dry matter intake, milk yield, and blood metabolites of periparturient Holstein dairy cows. J. Dairy Sci. $85: 879-888$

Pate, F. 1983. Molasses in Beef Nutrition. Natl. Feed Ingredients Assoc., W. Des Moines, IA.

SAS Institute. 1995. User's Guide: Statistics, Version 8 Edition. SAS Inst., Inc., Cary, NC.

Sannes, R. A., M. A. Messman, and D. B. Vagnoni. 2002. Form of rumen-degradable carbohydrate and nitrogen on microbial protein synthesis and protein efficiency of dairy cows. J. Dairy Sci. 85:900-908.

Smith, D. 1981. Removing and analyzing carbohydrates from plant tissue. Rep. No. R2107. Wisconsin Agric. Exp. Stn., Madison.
Strobel, H. J., and J. B. Russell. 1986. Effect of pH and energy spilling on bacterial protein synthesis by carbohydrate-limited cultures of mixed rumen bacteria. J. Dairy Sci. 69:2941-2947.

Sutton, J. D. 1997. Rumen function and the utilization of readily fermentable carbohydrates by dairy cows. Trop. Anim. Prod. $4: 1-12$.

Van Soest, P. J. 1994. Nutritional Ecology of the Ruminant. 2nd Ed. Cornell Univ. Press, Ithaca, NY.

Van Soest, P. J., J. B. Robertson, and B. A. Lewis. 1991. Methods for dietary fiber, neutral detergent fiber, and nonstarch polysaccharides in relation to animal nutrition. J. Dairy Sci. 74:35833597.

Varga, G. A. 2003. Soluble carbohydrates for lactating dairy cows. Proc., TriState Dairy Nutr. Conf., Fort Wayne, IN.

Vazquez-Añon, M., T. Cassidy, P. McCullough, and G. A. Varga. 2001. Effects of alimet on nutrient digestibility, bacterial protein synthesis, and ruminal disappearance during continuous culture. J. Dairy Sci. 84:159-166.

Yang, C. M. J., and G. A. Varga. 1989. Effect of three concentrate feeding frequencies on rumen protozoa, rumen digesta kinetics, and milk yield in dairy cows. J. Dairy Sci. 72:950-957.

Zinn, R. A., and F. N. Owens. 1986. A rapid procedure for purine measurement and its use for estimating net ruminal protein synthesis. Can. J. Anim. Sci. 66:157-166. 